\title{
THE WOMEN'S PARTY OF GREAT BRITAIN (1917-19): A FORGOTTEN EPISODE IN BRITISH WOMEN'S POLITICAL HISTORY
}

Article accepted for publication in June 2016 Issue of Women's History Review, a Special Issue edited by Barbara Bush, University of Sheffield and June Purvis, University of Portsmouth, titled Connecting Women's Histories: the local and the global, published by Routledge

Abstract

This article discusses the Women's Party, founded by Emmeline and Christabel Pankhurst in November 1917 at a time when Britain was still fighting in World War One. It examines the origins and aims of the Women's Party which, with the slogan 'Victory, National Security and Progress', conflated the winning of the war with the women's cause. It is contended that global politics on the world stage as well as local politics at home shaped the agenda of the Women's Party in many differing ways.

Biographical Data

June Purvis is an Emeritus Professor of Women's and Gender History at the University of Portsmouth, UK. She has published extensively on women's education in nineteenth-century Britain and on the suffragette movement in Edwardian Britain. Her publications include the edited Women's History Britain, 1850-1945 (London and New York: Routledge, 1995), The Women's Suffrage Movement: new feminist perspectives (co-edited with Maroula Joannou, Manchester: Manchester University Press, 1998), Votes for Women co-edited with Sandra Stanley Holton,London and New York: Routledge, 2000), Emmeline Pankhurst: a biography (London and New York: Routledge, 2002) and 'Fighting the double moral standard in Edwardian Britain: suffragette militancy, sexuality and the nation in the writings of the early twentieth-century British feminist Christabel Pankhurst' in Francisca de Haan, Margaret Allen, June Purvis and Krassimira Daskalova (eds) Women's Activism: global perspectives from the 1890s to the present (London and New York: Routledge, 2013). June is the Founding and Managing Editor of Women's History Review and also the Editor for a Series with Routledge on Women's and Gender History. She is Convenor of the Women's History Network (2014-18) and Treasurer of the International Federation for Research in Women's History (2015-2020). Correspondence to: Professor June Purvis, School of Social, Historical and Literary Studies, University of Portsmouth, Milldam, Burnaby Road, Portsmouth PO1 3AS, UK. Email: june.purvis@port.ac.uk 
In November 1917, while Britain was still at war, Emmeline Pankhurst and her eldest daughter Christabel, the leaders of the women-only Women's Social and Political Union (WSPU or Union), relaunched their organisation as the Women's Party. Whereas the WSPU, founded in 1903, had campaigned for the parliamentary vote for women and other wider social reforms that would bring equality to women, the aim of the Women's Party was to prepare women for their impending citizenship during wartime and after. The Women's Party, whose existence was short-lived, was unique in that it appears to have been the only attempt in Britain to found a political party exclusively for women. ${ }^{1}$ Yet in overviews of the topic of women and politics in twentieth century Britain the Women's Party is frequently not mentioned or given cursory coverage. ${ }^{2}$ When it is referred to, it is usually in derogatory terms, many authors taking their cue from Sylvia Pankhurst's influential narrative The Suffragette Movement, first published in 1931. Sylvia, a pacifist socialistfeminist who disagreed with her mother and sister Christabel over the WSPU policy and tactics, condemned their patriotic support for Britain and her Allies during the First World War, seeing their stand as a 'tragic betrayal' of the notion that women should stand for peace. ${ }^{3}$ Sylvia claimed that

\footnotetext{
${ }^{1}$ For brief as well as fuller references to the Women's Party see, for example, Pamela Brookes, Women at Westminster: an account of women in the British Parliament 1918-1966 (London: Peter Davies, 1967), p. 9; David Mitchell (1977) Queen Christabel: a biography of Christabel Pankhurst (London, MacDonald and Jane's), pp. 262-78; Margaret Stacey and Marion Price, Women, Power and Politics (London, Tavistock, 1981), p. 86; Brian Harrison, Prudent Revolutionaries: portraits of British feminists between the wars (Oxford, Clarendon Press, 1987), p. 35; Martin Pugh, The Pankhursts (London, Allen Lane, The Penguin Press,2001), pp. 340-50; June Purvis (2002) Emmeline Pankhurst: a biography (London and New York, Routledge), pp. 300-17; Nicoletta F. Gullace (2002) 'The Blood of Our Sons': men, women, and the renegotiation of British citizenship during the Great War (Basingstoke: Palgrave Macmillan), pp. 139-41; Angela K. Smith (2005) Suffrage Discoruse in Britain during the First World War (Aldershot: Ashgate), pp. 31-2; June Purvis (2007) The Pankhursts and the Great War, in Alison S. Fell and Ingrid Sharp (eds) The Women's Movement in Wartime: international perspectives, 1914-19 (Basingstoke: Palgrave Macmillan), p. 153-5.

${ }^{2}$ See, for example, Joni Lovenduski, Feminizing Politics (Cambridge: Polity Press, 2005) and Krista Cowman, Women in British Politics, c. 1689-1979 (Basingstoke, Palgrave Macmillan, 2010).

${ }^{3}$ E. Sylvia Pankhurst, The suffragette movement: an intimate account of persons and ideals (London: Longman, 1931), p. 595. Cowman, Women and British politics is one of the few who do not pass derogatory comments.
} 
the Women's Party was regarded by 'advanced women as a phalanx of the Tories', especially since it 'vehemently attacked the entire Labour movement..'

Scholars who came after Sylvia usually take a similar stand. Thus Brian Harrison claims that during her lifetime, Emmeline Pankhurst moved from the far left to the far right, and that women's claims came 'low down on the list' of the aims of the Women's Party. Julie Gottlieb states that the Women's Party borrowed freely from the agenda of the Right, confining its feminist content to the advocacy of improved housing. Martin Pugh asserts that the Women's Party was a right wing organisation that 'subordinated everything to the war effort' even claiming that it launched Christabel 'on the high road that leads to fascism.' Nicoletta Gullace calls it an 'ultra-nationalist' and 'ultra-conservative' organisation onto which was grafted a 'progressive feminist agenda'. ${ }^{5}$ But is this the whole story? How do these claims stand alongside Andrew Rosen's assertion that the Women's Party was 'a strange amalgam of apparently conflicting ideas'? ${ }^{6}$ It is my aim in this paper to explore the way that the global politics of a world war and the arrival of Bolshevism in Russia, on the one hand, together with the local British context of nationalism, pacifism and feminist politics, on the other, all interwove to present a more complex picture of the Women's Party than that usually presented.

\section{The origins of the Women's Party}

Emmeline was in St. Malo, France, on $1^{\text {st }}$ August when she heard the Mayor read out Germany's declaration of war against that country. Horrified and deeply upset by the news, her prejudices against all things German came to fore, especially when a few days later Germany then invaded the

\footnotetext{
${ }^{4}$ E. Sylvia Pankhurst, The Life of Emmeline Pankhurst: the suffragette struggle for women's citizenship (London: T. Werner Laurie, 1935), p. 163.

${ }^{5}$ Brian Harrison, Prudent revolutionaries: portraits of British feminists between the wars (Oxford: Oxford University Press, 1987), p. 35; Julie Gottlieb, Feminine fascism: women in Britain's fascist movement 19231945 (London: I. B. Tauris, 2000), p. 157; Martin Pugh, The Pankhursts (London: Allen Lane, 2001), pp. 340 \& 342; Nicoletta F. Gullace (2014) Christabel Pankhurst and the Smethwick election: right-wing feminism, the Great War and the ideology of consumption, Women's History Review, 23, 3, pp. 330 and 333.

${ }^{6}$ Andrew Rosen, Rise up women! The militant campaign of the Women's Social and Political Union 1903-1914 (London: Routledge \& Kegan Paul, 1974), p. 268
} 
small, neutral country of Belgium. On $4^{\text {th }}$ August, Britain declared war on the aggressor. Christabel had been living in Paris since March 1912, when she had fled there, to avoid being arrested by the police. Both ardent Francophiles, Emmeline and Christabel supported their country and its Allies, believing that the war was a just war. On 12 August 1914, a temporary suspension of WSPU militancy was announced until the conflict was over. As Christabel later explained, 'As suffragettes we could not be pacifists as any price ... We offered our service to the country and called upon our members to do likewise ... To win votes for women a national victory was needed for, as Mother said, "What would be the good of a vote without a country to vote in!" '7 Thus the war between Britain and Germany became a 'continuation' of the 'fight for freedom' that the suffragettes had engaged in, with Britain and her allies being defined as a 'feminine' nation and Germany as 'masculine' ${ }^{8}$ Widespread publicity about atrocities committed by the Germans, especially sexual violence against women, provided further justification - if needed - that the war was morally just. ${ }^{9}$

However, the WSPU did not abandon the campaign for votes for women - as many scholars have asserted - but changed its strategy. ${ }^{10}$ Emmeline and Christabel Pankhurst became 'patriotic feminists' supporting their own country and its Allies, weaving into their speeches themes about the nation, patriotism, imperialism, democracy, internationalism, men's and women's contribution to the war effort, the benefits of women's war service, and women's enfranchisement. ${ }^{11}$ As Gullace has observed, Emmeline and Christabel were able to take control of the discourse, drama and spectacle of war to serve their own ends and further the campaign for female citizenship. In so doing they demolished the anti-suffrage argument and helped to bring about a cultural shift in the definition of citizenship so that it centred on the idea of loyal service, patriotic sentiment and British

\footnotetext{
${ }^{7}$ Christabel Pankhurst, Unshackled: the story of how we won the vote (London: Hutchinson, 1959), p. 288.

${ }^{8}$ Gullace, 'The Blood of Our Sons', p. 122, and Jacqueline de Vries (1994) Gendering patriotism: Emmeline and Christabel Pankhurst and World War One, in Sybil Oldfield (ed.) This Working-Day World: women's lives and culture(s) in Britan 1914-1945 (London: Taylor and Francis), p. 77.

${ }^{9}$ See Susan Kingsley Kent (1993) Making Peace: the reconstruction of gender in interwar Britain (New Jersey: Princeton University Press), pp. 22 and 75.

${ }^{10}$ For a recent view that the WSPU abandoned all campaigning for the vote see, for example, Lindsey German (2013) How a Century of War Changed the Lives of Women (London: Pluto Press), p. 19.

${ }^{11}$ Purvis, Emmeline Pankhurst, p. 269.
} 
blood rather than manhood, the age of majority or property qualifications. ${ }^{12}$ On 19 June 1917, the House of Commons voted by 387 to 57 in favour of the women's clause in the Representation of the People Bill which would give the parliamentary vote to women aged 30 and over who were householders, the wives of householders, occupiers of property or $£ 5$ or more annual value, or university graduates. ${ }^{13}$ Although, in the autumn of 1917 , the Bill was waiting to go through the House of Lords, Emmeline and Christabel knew that the long, hard fight to break the sex discrimination against women exercising the parliamentary vote was over and that the WSPU would now be redundant. The key task was now preparing women for their enfranchisement and so the WSPU was given a change of direction and renamed the 'Women's Party'.

\section{The aims of the Women's Party}

To the Pankhursts, it must have seemed 'a logical move' to create a political party for women; afterall, the two established political parties - the Liberals and the Conservatives - had shown much hostility to women's enfranchisement on the terms that they had demanded, that is the parliamentary vote for women on the same terms as it is, or shall be, granted to men. ${ }^{14}$ The structure of party politics was such that neither of the two main parties could agree on which groups of women should be enfranchised since both looked at the issue of female enfranchisement in terms of party advantage. Such a vision, as Richard Toye has argued, had 'stymied' any change, which only became possible under the altered conditions of a coalition government during the Great War. ${ }^{15}$ Following the women-centred approach of the WSPU, Emmeline and Christabel noted that while the Women's Party was in no way based on sex antagonism, 'it is felt that women can best serve the nation by keeping clear of men's party political machinery and traditions, which, by universal

\footnotetext{
${ }^{12}$ Gullace, 'The Blood of Our Sons', pp. 118-9.

${ }^{13}$ Harold L. Smith (1998) The British Women's Suffrage Campaign 1866-1928 (London: Pearson Education), p. 88 notes that 8,400,000 women were enfranchised under this Act, comprising $39.6 \%$ of the electorate.

${ }^{14}$ Anna Coote and Polly Pattullo, Power and prejudice: women and politics (London: Weidenfeld and Nicholson, 1990), p. 161.

${ }^{15}$ Richard Toye, Lloyd George \& Churchill: rivals for greatness (Basingstoke, Macmillan, 2007), p. 77.
} 
consent, leave so much to be desired. ${ }^{\prime 16}$ As Emmeline explained, women needed a party of their own because 'men had grown so accustomed to managing the world in the past that it had become rather difficult for women in politics to hold their own if they were associated with men'. ${ }^{17}$ Thus although men were invited to join the Women's Party as sympathisers, the main appeal was to women. It was women who could bring about the political and moral rejuvenation of Britain. ${ }^{18}$ With the slogan 'Victory, National Security and Progress', the Women's Party conflated the winning of the war with the women's cause. Global politics on the world stage clearly helped to shape the agenda of the Women's Party just as much as local conditions on the home front.

The separatist Women's Party manifesto was signed by four key members of the inner circle of the old WSPU - Emmeline Pankhurst its Honorary Treasurer, Christabel the Editor of its official newspaper, Britannia, Annie Kenney its Honorary Secretary, and Flora Drummond, the Chief Organiser - and printed in the issue of Britannia dated 2nd November 1917. The aims of the Women's Party in regard to the war were patriotic, anti-pacifist and imperialist, reiterating many of the ideas that Emmeline and Christabel had articulated earlier in various speeches and campaigning literature. Although 'Down with pacifism everywhere' was asserted to be the chief cry of the Women's Party, other more radical war measures were also advocated, including better coordination of the Allied command, food rationing and the reduction of non-essential industry. ${ }^{19}$ Efficient and loyal public service could be guaranteed, it was argued, by ridding all Government departments of officials who had enemy blood or connections or pacifist and pro-German leanings. The Naturalisation Laws should be changed too, to prevent Germans and their allies acquiring British nationality and exploiting it after the war, as they had done in the past. On the Irish question, the Women's Party was strictly Unionist while support was voiced for strengthening the British Empire so that its natural resources and transport system came under British ownership and control. In

\footnotetext{
16 The Women's Party (London: The Women's Party, n.d.), p. 1.

${ }^{17}$ Britannia, 23 November 1917, p. 196.

${ }^{18}$ Gullace, Christabel Pankhurst and the Smethwick election, p. 10; Join the Women's Party, Britannia, 11 October 1918, pp. $155 \& 157$.

${ }^{19}$ Britannia, 22 March 1918, p. 386.
} 
regard to the problem of industrial unrest in Britain, it was suggested that a solution could be found in shortening the hours of labour rather than in the Marxist direction of control of industry by the workers. Since the interests of the community as a whole transcended that of the employer and the employed, Parliament as the sole democratic representative of the nation should have the 'last word in all questions affecting the relations between Capital and Labour and industrial questions generally. ${ }^{\prime 20}$ 'The Women's Party will use the vote to make Britain strong for defence against the outside foe', editorialised Britannia, 'and to strengthen Britain from within by securing more prosperous and more harmonious national development in its education, industrial, political and social aspects. ${ }^{21}$ Further, it was the Women's Party that was the party of progress, offering an alternative to those women who did not want to ally with the Labour Party. We warn women, declared Christabel 'to have nothing to do with the Labour Party, riddled as it is by Bolshevism'. ${ }^{22}$ The Women's Party, Christabel insisted, amid loud cheers, stands 'first for the defence of our frontiers, and then reforms inside our frontiers, to make life worth living and fighting for. ${ }^{23}$

Such sentiments echoed those of most Conservatives of the day. Anti-socialism was generally part of the Conservative political culture with the term 'bolshevik' often being used as a synonym for 'socialist', even by some with Labour sympathies. ${ }^{24}$ But the Women's Party diverged widely from Conservative thinking in regard to the progressive feminist and industrial programmes that it advocated. In regard to the second section of the Women's Party manifesto, subtitled 'Special Women's Questions' the proposed social reform post-war programme was feminist, radical and wide ranging, incorporating many of the progressive feminist ideas of the time. ${ }^{25}$ Emmeline and Christabel had not abandoned feminism. Thus the Women's Party advocated equal pay for equal

\footnotetext{
${ }^{20}$ Britannia, 2 November 1917, p. 172.

${ }^{21}$ Britannia, 11 January 1918, p. 241.

${ }^{22}$ Britannia, 1 February 1918, p. 274.

23 'Against Britain's Bolsheviks, Miss Christabel Pankhurst's Denunciation of Mr. Ramsay MacDonald', Britannia, 25 January 1918, p. 270.

${ }^{24}$ Clarisse Berthezene (2015) Training the Minds for the War of Ideas: Ashridge College, the Conservative Party and the cultural politics of Britain, 1929-54 (Manchester: Manchester University Press), p.12.

${ }^{25}$ See Britannia, 2 November 1917, pp. 171-2 for the programme.
} 
work, equal marriage and divorce laws, equality of parental right, the raising of the age of consent, equal opportunity of employment, and equality of rights and responsibilities in regard to the social and political service of the nation. A system of maternity and infant care was called for, with parents making a financial contribution according to their income, as well as a guarantee that all children would receive an education that would make them worthy citizens. Co-operative housekeeping was advocated, as a way to reduce the burden of wives and mothers and raise the standard of living of the mass of the people, together with co-operative housing schemes that had central heating, a hot water supply, central kitchen, central laundry, medical services and, if desired, a crèche, nursery school, gymnasium and reading room. ${ }^{26}$

Both Emmeline and Christabel believed that all this could be achieved, not by emphasising the class divisions and class hatred so central to Marxism and Bolshevism but through class cooperation. 'We are in favour of class harmony, and of outgrowing class distinctions', cried Christabel. ${ }^{27}$ Industrial reform should come not from the Marxist notion of worker control of industry - which the Women's Party strongly opposed - but through increasing industrial output, cutting working hours and improving working conditions. The Marxist cry of 'Up with the Proletariat and down with the Bourgeoisie!' was nonsense, 'indeed madness. ${ }^{.28}$ As democrats, the leaders of the Women's Party could not tolerate such a system whereby workers would be marked off from their fellow citizens by peculiarities of speech, deportment and uncouthness. The solution was to abolish the proletariat, something that could be done by bringing the comforts, refinements and luxuries that had been the monopoly of the few to the masses. What was needed was increased production accompanied by increased consumption. In this process of moving towards a more equal society, the paid employment of women was an economic boom. Women workers had a crucial part to play since they not only increased the prosperity of the nation, but through their

\footnotetext{
${ }^{26}$ Britannia, 2 November 1917, p. 171.

${ }^{27}$ Britannia, 9 November 1917, p. 190.

${ }^{28}$ Christabel Pankhurst, 'Industrial salvation', Britannia, 30 August 1918, p. 107.
} 
purchasing power, provided employment for others. Christabel concluded her plan for 'Industrial Salvation' as she termed it, by noting that in the happier time towards which the Women's Party was striving, the high standard of living of the upper classes would be 'as natural and as open to all, without distinction of class, as the free air of heaven.' ${ }^{29}$ To assert therefore, as Gullace does, that the Women's Party upheld a 'consumer-based feminism' is to overstate the case. ${ }^{30}$ It is important to stress that it was hoped that the Women's Party would appeal to women in all social classes. In order to do this, the programme had to be diverse, to attract working-class women as well as those who were higher up the social hierarchy.

The Women's Party, at its launch, received enthusiastic reviews from a right wing press concerned about the growing influence of what seemed like an unstoppable Labour Party at home and the rise of Bolshevism in Russia in the international context. The war was hastening the collapse of the old social order in Britain while the echoes of the new Bolshevik regime in Russia 'sang across Europe. ${ }^{\prime 31}$ Significantly, the Women's Party's anti-Bolshevik campaign attracted the approval of the British Government as well as the support of leading industrialists, such as Lord Leverhulme. Additionally, the British Commonwealth Union, a recently formed protectionist organisation that aimed to influence the post-war Conservative Party, courted the Women's Party and gave it money to help fund its campaign against industrial militancy. ${ }^{32}$ Thus the gulf widened between socialist feminists and feminists such as Emmeline and Christabel who were not allied to socialism, a not unexpected development since many feminists who shared the world-wide reaction against Bolshevism were driven to the right. ${ }^{33}$ In particular, both Emmeline and Christabel believed that the pacifist socialism

\footnotetext{
${ }^{29}$ Christabel Pankhurst, 'Industrial salvation', Britannia, 30 August 1918, p. 109.

${ }^{30}$ Gullace, 'Christabel Pankhurst and the Smethwick election', p. 332.

${ }^{31}$ Beatrix Campbell (1987) The Iron Ladies: why do women vote tory? (London:Virago), p. 56

${ }^{32}$ Martin Pugh (2001) The Pankhursts (London: Allen Lane), p. 341-2

${ }^{33}$ E. C. Dubois (1998) Women suffrage and women's rights (New York, New York University Press), pp. 272-3.
} 
upheld by Labour Party men such as Ramsay McDonald, had not well served the national interest during wartime..$^{34}$

If many on the right welcomed the Women's Party, for some on the left it was an object of contempt. In particular, Sylvia Pankhurst commented that 'too much importance' should not be attached to the new organisation which was 'using the name "Women's" in a way which none of us could accept.. ${ }^{35}$ Emmeline and Christabel ignored such criticisms. Christabel's message of sex equality, patriotism, improvement in women's working conditions and industrial peace appealed to a wide range of the female population, including middle-class and working-class employees such as schoolteachers and munition workers. In particular, the number of women working in the munitions factories, as Angela Woollacott has noted, were far more numerous than those serving in any other wartime role. ${ }^{36}$ A large number of these women, despite the dirty and dangerous nature of the work, were patriotic, some having moved from other forms of employment, such as weaving, in order to help the troops, thinking it was 'the right thing to do'. ${ }^{37}$ As Naomi Loughnan assured her readers, 'Though we munition workers sacrifice our ease we gain a life worth living. Our long days are filled with interest, and with the zest of doing work for our county in the grand cause of freedom. ${ }^{38}$ Seen as a 'powerful symbol of modernity', the female munition worker 'challenged the gender order through her patriotic skilled work and control of machinery, and ... undermined class

\footnotetext{
${ }^{34}$ Britannia, 25 January 1918, pp. 269-70; Purvis, Emmeline Pankhurst, p. 305; June Purvis (2013) Emmeline Pankhurst in the aftermath of suffrage, 1918-1928, in Julie V. Gottlieb and Richard Toye (eds) The aftermath of suffrage: women, gender, and politics in Britain, 1918-1945 (Basingstoke: Palgrave Macmillan), p. 20.

${ }^{35}$ The Labour Woman, November 1918, p. 76

${ }^{36}$ Angela Woollacott (1994) On Her Their Lives Depend: munitions workers in the Great War (Berkeley, University of California Press), p. 1. Kate Adie (2013) Fighting on the Home Front: the legacy of women in World War One (London: Hodder and Stoughton), p. 125 states 'From the Kyle of Bute in Scotland to the mines of Cornwall, from the gentle chalk streams of Hampshire to the huge arsenal at Waltham Abbey in Essex, the munitions industry thrived - and suffered spectacular accidents.'

${ }^{37}$ Gail Braybon and Penny Summerfield (1987) Out of the Cage: women's experiences in two world wars (London: Pandora Press), pp. 58-61. Deborah Thom (1998) Nice Girls and Rude Girls: women workers in World War I (London and New York: Tauris), p. 152 notes that one of her witnesses who had worked on the shopfloor in the Woolwich Arsenal spoke of an ex-suffragette she met working beside her. 'You'd never have known it. They were so nice, such ladies.'

${ }^{38}$ Naomi Loughnan in Gilbert Stone, (1917) Women War Workers (London: Allen and Unwin), p. 137, quoted in Braybon and Summerfield Out of the Cage, p. 62.
} 
differences through her spending power. ${ }^{39}$ Consequently they were frequently criticised by both the right and left, chastised for their high wages and frivolous spending habits. Indeed, fears that highly paid factory women might drink heavily and engage in petty crime, including smuggling forbidden items such as cigarettes in the vicinity of high explosives, lead the Ministry of Munitions to appoint several hundred policewomen in an attempt to control their behaviour. ${ }^{40}$

However, contrary to the assertion of some historians, Christabel Pankhurst was not amongst those who were critical of female munition workers. ${ }^{41}$ Instead she championed their cause, demanding equal pay for equal work and for equal treatment of demobilised men and women. On more than one occasion she spoke at Woolwich Arsenal when women were dismissed from their posts, praising the loyalty of the women and condemning those men who were shirkers, strikers or pacifists. 'These miserable creatures threaten to strike', she told one large appreciative, female audience:

Well, if they do go out, lock the gates on them and never let them back. (Applause). They are holding their country to ransom ... Keep the women in the factories, and send these "skilled" workers to the Western front ... The women can turn out more stuff than these slackers will. (Applause). ${ }^{42}$

\footnotetext{
${ }^{39}$ Woollacott, On Her Their Lives Depend, p. 3. Susan R. Grayzel (1999) Women's Identitites at War: gender, motherhood, and politics in Britain and France during the First World War (Chapel Hill and London: University of North Caroline Press), p. 5 emphasizes the 'dual significance' of women's war work as 'production and reproduction' and concludes, p. 119 that, on the one hand, both the governments of Britain and France encouraged women's patriotic participation in war work, and on the other, 'they felt compelled to safeguard motherhood as anxiety about declining birthrates grew as the war's death tolls mounted.'

${ }^{40}$ Woollacott, On Her Their Lives Depend, pp. 174 -79; Nina Boyd (2013) From Suffragette to Fascist: the many lives of Mary Sophia Allen (Stroud, The History Press), pp.68-72.

${ }^{41}$ See, for example, Woollacott, On Her Their Lives Depend, p. 165 'Sylvia Pankhurst .... monitored conditions and issues in munitions factories throughout the war ... Emmeline and Christabel Pankhurst expressed no interest in working-class women's issues....'.

${ }^{42}$ Woolwich Herald, 8 March 1918, reprinted in Britannia, 15 March 1918, p. 372. Woollacott, On Her Their Lives Depend, p. 2 notes that the women munition workers constituted the army of women who were 'most directly involved in supplying the forces and thereby conducting the war on the home front. They were the first stage in the production line of death that ended at the front; they were well aware of the lethal nature of their manufactures and believed themselves to be essentially involved in the conduct of war.' Gail Braybon (1981) Women Workers in the First World War (London and New York: Routledge), p. 46 notes that by 1916 there was
} 
With such well-chosen words, Christabel became a popular figure amongst the women munition workers who welcomed her praise for their war work, the emphasis upon sexual equality and the appeal to their patriotism. Christabel went further, dismissing those male socialists who condemned working women for trying to better themselves:

The I.L.P lecturer works himself up into a frenzy in his efforts to incite the working woman to the class war. He tries to rouse her to class jealously by his denunciation of 'the employer's wife in her silk dress.' But the working woman simply and calmly adheres to her determination, not to prevent the employer's wife from having a silk dress, but to have a silk dress too! ... The working women who spend their earnings on silk dresses, silk stockings, shapely shoes, fine underwear, fur coats, pretty hats, and all the rest of it, are far better social reformers than all the men's Socialist or Labour organisations rolled into one ... They are raising their standard of living, and they are doing their best to break down class distinctions, which are so largely a question of dress, speech, and deportment. ${ }^{43}$

The embourgeoisement of the female munition worker which both Christabel and the Women's Party upheld was seen as an effective antidote to the rise of Bolshevism and the spread of socialism, a theme that became increasingly emphasised in Christabel's speeches as the war progressed and the outcome seemed uncertain. The tone of her talks became increasingly rabid and tough. Thus in May 1918, when speaking to her supporters at the London Pavilion, Christabel stressed that the war

\footnotetext{
a shortage of female labour in the textile and clothing trades, as women moved into the more lucrative munitions work. At Woolwich Arsenal only 125 women were employed in 1914 - by 1917 this had risen to 25,000. For a useful overview on women and the First World War see Susan R. Grayzel; (2002) Women and the First World War (Harlow, Pearson Education).

${ }^{43}$ Christabel Pankhurst, To abolish the proletariat, Britannia, 6 September 1916, p. 116, reprinted in Christabel Pankhurst, Industrial Salvation (London: The Women's Party, 1918), pp. 12-3.
} 
aim of the Women's Party was the crushing of Germany. They must have no qualms about that, for either Germany must be crushed, or Britain must be crushed. There could only be one winner. Anything which tended to delude Britons into believing that the German people were not in the same boat as their Kaiser, or that there was some hope of human and civilised feelings on the part of the German Socialists, was dangerous and even criminal:

The Kaiser still represented his savage and aggressive people, and whenever the German Socialists began to hold out the olive branch they could rely on the whole thing being cunningly conceived in the hope that their accomplices in this country would to ready to second their overtures. The best antidote to Bolshevism was woman. ${ }^{44}$ However, as the Allies gained the upper hand in the last months of the war, the rhetoric of the Women's Party stressed much more the local context, particularly the contribution that women could make to bringing about better conditions on the home front. This was the focus of a Women's Party meeting held in Derby in September 1918. It was the women of the country who were going to run the scale between Bolshevism and true constructive progress, said Christabel at this event. Yet better conditions could only be maintained when the proletariat was abolished. Women had now got a footing in the industrial field, 'and they were going to stay there.' Women were not going to be turned out of their well-paid work and sent back to the sweated industries, a proposition that was made without their consent. 'They were going to have equal pay for equal work, but were not going to be exploited by Bolshevic [sic] enemies. ${ }^{45}$ By October 1918, when it was clear that the Allies were winning the war, the Women's Party were holding 'Victory Meetings' ${ }^{46}$

\footnotetext{
44 'Women as antidote to Bolshevism, No delusions about Germans', Britannia, 31 May 1918, p. 476.

45 'Women's Party at Derby', Britannia, 13 September 1918, p. 124.

${ }^{46}$ See title page of Britannia, 4 October 1918, 'The Victory Meetings Held by the Women's Party every Tuesday Afternoon at 3 o'clock in the Large Queen's Hall, begin Tuesday, October 8'.
} 
Shortly after the Armistice was called on 11 November 1918, a bill was rushed through parliament which made women eligible to stand for election to the House of Commons on equal terms with men, with no age barrier. In practice this meant that women aged between twenty one and thirty, could stand as parliamentary candidates but were not allowed to exercise the parliamentary vote themselves! The irony of the situation was undoubtedly not lost on members of the Women's Party. Since the bill passed into law on 21 November 1918, it gave the Women's Party just over three weeks to field any candidates for a general election that would take place on 14 December. Many of Emmeline's friends wanted her to stand for election, but Emmeline wanted this honour not for herself but for the much younger Christabel, her favourite daughter whose political insight she greatly admired.

Presiding over a Women's Party meeting held on 19 November, Emmeline announced, to much cheering, that Christabel was the 'candidate best fitted to be our spokeswoman' and 'the best representative our party can find.' Christabel was not only an idealist and a practical politician, but 'the strategist who drew up the plan of campaign which had the result of taking the question of the citizenship of women out of the region of fads into practical politics'. We have, Emmeline continued, 'to see that the peace is won, that it shall be secure peace for many generations to come. We have to see that the programme of the Women's Party for Social Reconstruction and Reform is put forward in Parliament by the one who has had the greatest part in its authorship. ${ }^{47}$ Christabel, for her part, in a brief speech accepting her nomination addressed the key themes of the Women's Party manifesto, telling her audience of men and women that she would try to get elected to parliament where she hoped it may be possible to do some good. 'I shall try; I shall do my best; we cannot do more. (Cheers). I thank you with all my heart for your kindness and your trust. ${ }^{\prime 48}$

Initially Christabel was to stand for the Westbury Division of Wiltshire and, as expected, had the backing of Lloyd George, the Prime Minister of the Coalition Government. Lloyd George, who did

\footnotetext{
${ }^{47}$ Mrs. Pankhurst, 'To win the peace', Britannia, 22 November 1918, p. 203.

48 'The candidate's speech', Britannia, 22 November 1918, p. 205
} 
not have the support of all Liberal MPs, many still remaining loyal to Asquith, decided to fight the election in conjunction with Bonar Law, the leader of the Conservative Party, since this would give him the best chance of retaining the premiership. It was decided that the preferred candidates of this Conservative and Coalition Liberal group would be given a 'coupon' or letter of approval which would greatly increase the chances of success. ${ }^{49}$ Of the seventeen women standing for parliament, Christabel was the only one to receive the coveted coupon. 'The Women's Party, of which Miss Pankhurst is the Leader, has been extraordinarily useful, as you know, to the Government', Lloyd George wrote to Bonar Law. 'They fought the Bolshevist and Pacifist element with great skill, tenacity and courage, and I know especially in Glasgow and South Wales their intervention produced remarkable results. ${ }^{50}$ However, Christabel changed her mind about contesting Westbury and opted instead to stand in the new, working-class constituency of Smethwick, an industrial town with massive engineering works as well as glass factories and large breweries, close to Birmingham. The presence of 12,736 women voters on the electoral register in Smethwick, many of whom were industrial workers, may have been an important factor influencing her decision to switch constituencies - as well as the challenge of standing against a candidate for the detested Labour Party. Nonetheless, there were also in Smethwick 14,789 men voters as well as an additional 5,393 absent voters in the armed forces who were entitled to a postal vote. ${ }^{51}$

Christabel's campaign was financed by donations from sympathetic women and by a $£ 1,000$ cheque from the British Commonwealth Union. ${ }^{52}$ Lord Northcliffe, the powerful press proprietor who owned both The Times and The Daily Mail, was also supportive. In her election leaflet, Christabel was described as the 'Patriotic Candidate for Smethwick and Supporter of the Coalition'. And she pledged, if elected to parliament, to work for two main objectives - first, to secure a lasting peace based on material guarantees against future German aggression and, second, to improve the

\footnotetext{
${ }^{49}$ Pugh, The Pankhursts, p. 343.

${ }^{50}$ Lloyd George to Bonar Law, 21 November 1918, Lloyd George Papers, House of Lords Record Office (hereafter HLRO, F/30/2/55.

${ }^{51}$ The Times, 28 November 1918.

${ }^{52}$ Purvis, Emmeline Pankhurst, p. 313.
} 
social conditions of the working classes through a levelling up of society, by social reform, industrial salvation and wealth production. Her determination, Christabel asserted, 'to work for the Abolition of Poverty, by increasing Wealth Production, and Democratising Prosperity' was one of her main reasons for seeking election to parliament. If elected, she would give special attention to housing schemes that included bathrooms, central hot water supplies, central kitchens and laundries which would all help to relieve the drudgery of hard-pressed women in the home. The welfare of children was another important consideration. 'A good Education is the birthright of every child, and I shall do my utmost to give equal education opportunities to all. ${ }^{53}$ Christabel also supported the provision in public houses of music and refreshments, as a way to make them 'fit places' that women would want to enter. ${ }^{54}$ The Women's Party therefore embodied much more than an ideology of consumption, as Gullace has claimed. ${ }^{55}$

Dubbed by the press as 'The Portia of the Suffragists and their most brilliant orator', Christabel addressed about sixty indoor and outdoor meetings in the short time to polling day. ${ }^{56}$ She reached out to a wide spectrum of the electorate, including the absent voters in the armed forces to whom she send a special address. ${ }^{57}$ Her picture appeared frequently in the papers with groups of mothers and children, members of the general public, sailor or soldier supporters. ${ }^{58}$ In an attempt to unseat the Labour candidate, J. E. Davison, Christabel focused on the inadequacies of the Labour Party. 'The Women's Party is the true Labour Party', she reiterated on a number of occasions. 'We aim at the abolition of poverty by the increased production of wealth so that there may be enough wealth for all. ${ }^{59}$ When she denounced the Labour Party as a party corrupted by Bolsheviks and led by Bolsheviks, charges that were commonly made by Conservative candidates during the 1918 election,

\footnotetext{
${ }^{53}$ Miss Pankhurst's Election Address, General Election December $14^{\text {th }} 1918$, leaflet published by E. E. Bowerman, Smethwick, nd, Kenney Papers.

${ }^{54}$ Smethwick Telephone, 7 December 1918.

55 Gullace, Christabel Pankhurst and the Smethwick election.

${ }^{56}$ Smethwick Telephone, 7 December 1918.

${ }^{57}$ Britannia, 20 November 1918, p. 211.

${ }^{58}$ See Daily Mirror, 9 and 12 December 1918; Daily Sketch 9 December 1918

${ }^{59}$ Daily Mail, cited in Britannia, 6 December 1918, p. 222.
} 
the exchange of views became particularly fiery. ${ }^{60}$ Despite the fact that Christabel had gone down with influenza, her supporters were enthusiastic, as was much of the press. On the eve of the election The Times claimed, 'Miss Pankhurst is a fighter ... [who] has made steady progress ... It is believed her majority will be large. ${ }^{61}$ But it was not to be. Christabel lost the election by the narrow margin of 775 votes.

Emmeline took the news more badly than Christabel who, by now, had become a Second Adventist, that is a Christian who is expecting the imminent return of Christ. Nonetheless, a few days after the general election, Christabel spoke to the press, noting that the women candidates did not have a chance of success since, unlike the men, they had had only a short time in which to prepare. 'I intend to become a candidate again at the first available by-election', she said, indicating that she still had political ambitions. 'My opponent's majority was so small that I consider it justifies my again seeking election at the earlier possible moment. ${ }^{162}$

Within a few weeks, Christabel announced that she would contest the Westminster Abbey constituency at the next General Election. However, many obstacles lay in her path, not least that the Women's Party was in debt. Although help was sought from the British Commonwealth Union, Patrick Hannnon, its General Secretary, was unwilling to co-operate. 'Our relations with the Women's Party here have been unsatisfactory beyond words', he complained irritably in late March 1919. ${ }^{63}$ Despite uncertainty about the future for the Women's Party, Christabel continued to work on its behalf. In particular, at this moment in time she became deeply concerned about the peace proceedings to end the First World War, being held in Paris. Although peace had returned to the Western fronts, fighting was still being waged elsewhere, particularly in Russia where there was a civil war. Neither the old Russia nor the new Soviet Union had sent delegates to the talks over which

\footnotetext{
${ }^{60}$ Mary Hilson, Women voters and the rhetoric of patriotism in the British general election of 1918 , Women's History Review, Vol. 10, no 2, 2001, p. 334.

${ }^{61}$ The Times, 14 December 1918.

${ }^{62}$ Daily Sketch, 30 November 1918.

${ }^{63}$ Patrick Hannon, Relations with Women's Party, 23 January 1919, Box 11/5, Hannon Papers, HLRO.
} 
the threat of a 'Bolshevik tide' hovered. ${ }^{64}$ Fearing that too much was being given away to the defeated enemy, Germany, at the cost of weakening the alliance between Britain and France, Christabel was determined to make her voice heard. She not only wrote an article for the Daily Sketch - 'Are We Forsaking France? Why Britain Must Be Loyal To Her Ally In Demanding Frontiers Essential To A World Peace' - but also travelled to Paris, seeking to influence the peace proceedings. ${ }^{65}$ 'I hope you can arrange to spare time today for a good long talk', she wrote to Lloyd George from her Paris hotel on 5 April. ${ }^{66}$ It is doubtful that she did met up with Lloyd George but she did converse with some of the important delegates, including the Prime Minister of Australia, Billy Hughes, who wanted Germany to repay the estimated $\mathrm{f364}$ million that the war had cost his country.

By mid-April, Christabel was back in England, ready to give the first of a series of six talks as the prospective Women's Party candidate for the Abbey Division of Westminster. She was devastated when Annie and Jessie Kenney, two of her closest friends from her suffrage days, decided that they must temporarily leave the Women's Party. Tired and not in good health, Annie and Jessie decided that they needed to take a three month recuperative trip abroad. Without her two oldest and closest friends by her side, Christabel felt lost - and uncertain - despite her mother's keenness that she should be elected to parliament. 'Mother ... is absolutely bent upon my getting elected', she had earlier told Lloyd George. ${ }^{67}$ But no by-election was called in the Westminster Abbey Division and worse, there was no money to support any future parliamentary candidature for Christabel. The British Commonwealth Union had stopped its financial contributions while donations from other

\footnotetext{
${ }^{64}$ Zara Stenier, The peace settlement, in Hew Strachen (ed) The Oxford Illustrated History of the First World War (Oxford: Oxford University Press) p. 291

${ }^{65}$ Daily Sketch, 4 April 1919.

${ }^{66}$ Christabel Pankhurst to Lloyd George, 5 April 1919, Lloyd George Papers, HLRO.

${ }^{67}$ Christabel Pankhurst to Lloyd George, 21 November 1918, Lloyd George Papers.
} 
supporters dried up. Without representation in parliament and without funds, the Women's Party faded away. ${ }^{68}$

The Women's Party was the first and last serious attempt by women in Britain to found their own political party - and it failed for three main reasons. First, women's voting patterns were not necessarily unified on the issue of their gender; class and political party affiliations could criss-cross and ultimately outweigh gender loyalty. Second, the young female factory workers who admired Christabel were unable to vote for her; the unequal franchise for women only granted the vote to certain categories of women over the age of thirty. Third, less than $55 \%$ of the electorate voted at Smethwick anyway and those who did included men who may have been reluctant to vote for a party with such a gendered name. ${ }^{69}$

As has been shown here, local and global influences during wartime, as well as the feminist interests of its founders, shaped the rhetoric and policies of the Women's Party. Rather than ally the Women's Party to any of the main political parties of the day which Emmeline and Christabel Pankhurst found sadly lacking, they sought to create an independent party that would appeal to all women, irrespective of social class or political affiliation, a patriotic party that supported the war effort and was strongly opposed to pacifism. Most commentators, especially feminist commentators, have condemned such a move as right wing.

Part of the problem is that feminist commentators, especially in the last thirty years or so, have assumed that feminism and pacifism are compatible while feminism and support for war are not. ${ }^{70}$ Thus 'patriotic' or 'pro-war' women have been seen as less attractive to study, less worthy than

\footnotetext{
${ }^{68}$ For an influential broad discussion on the way in which the war reinforced the idea of woman's place within the home see Susan Kingsley Kent (1993) Making Peace: the reconstruction of gender in interwar Britain (New Jersey, Princeton University Press). For a critique of Kent and other relevant writing in the field see Gail Braybon (2003) Winners or losers: women's symbolic role in the war story, in Gail Braydon (ed) Evidence, History and the Great War: historians and the impact of 1914-18 (Oxford: Berghahn Books), pp. 86-112. ${ }^{69}$ On these last two points see especially Gullace, 'Christabel Pankhurst and the Smethwick Election'.

${ }^{70}$ For an early expression of this view see, for example, Coote and Pattullo, Power and prejudice, p. 163 where they state that, despite the 'impressive [feminist] chunk' of the Women's Party manifesto, it was not interested in creating a gender-based politics. 'It was as much an anti-pacifist party as a pro-women's party.'
} 
radical left wing women. ${ }^{71}$ But not all feminists during the First World War were pacifists, as this study of the Women's Party illustrates. And not all pro-war women would have accepted the policies of the Women's Party, especially those that did not relate to women per se.

A study of the Women's Party of Great Britain raises many important other issues, not least - how should feminists organise politically? Should they organise in separate women-only organisations or should they take part in male-dominated power structures with all their problems? It is an issue that is still of relevance today in Britain as women remain under-represented in parliament and unequal in many areas of life. And it was the prevalence of these prevailing gender inequalities in 2015 , in a vastly different social and cultural context to that of 1917 , that forced the topic to erupt unexpectedly once again when, in March of that year, a 'Women's Equality Party' was formed by two feminists - Catherine Meyer, author and former Time magazine editor and Sandi Toksvig, an acclaimed radio and TV presenter and comedian. Within four months, another feminist, Sophie Walker, a former Reuters journalist, had been appointed as its leader. ${ }^{72}$ However, unlike the Women's Party, the Women's Equality Party is aimed at attracting 'all genders', not just women, to work together to eradicate women's inequality. ${ }^{73}$ Yet the aims of the 'new' mixed sex women's party, which intends to field candidates in local and general elections, sound remarkably similar to

\footnotetext{
${ }^{71}$ On this point see, for example, Nicolette F. Gullace (1997) White feathers and wounded men: female patriotism and the memory of the Great War, Journal of British Studies, 36, pp. 178-206. For further discussion of women and patriotism during the First World War see, for example, Paul Ward (2001) 'Women of Britain Say Go': women's patriotism in the First World War, Twentieth Century British History, 12, 1, pp. 2345; Jo Vellacott (2007) Pacifists, Patriots and the Vote: the erosion of democratic suffragism in Britain during the First World War (Basingstoke, Palgrave MacMillan); Matthew C. Hendley (2012) Organized Patriotism and the Crucible of war: popular imperialism in Britain, 1914-1932 (Montreal and Kingston, McGill-Queen's University Press); David Monger (2012) Patriotism and Propaganda in First World War Britain: the National War Aims Committee and civilian morale (Liverpool: Liverpool University Press); David Monger (2014)

Nothing special? Propaganda and women's roles in late First World War Britain, Women's History Review, 23, 4, pp. 518-42.

${ }^{72}$ See Sandi Toksvig campaigns for equality with new political party, 30 April 2015, http://www.bbac.co.uk/news/entertainments-arts-32531750 accessed 16 May 2015 and Tracy McVeigh, 'We're not pushing women at the expense of men. Equality just makes things better', The Observer, 18 October 2015, p. 7.

${ }^{73}$ McVeigh, 'We're not pushing women at the expense of men ...', p. 7; an advertisement for the Women's Equality Party meeting to be held at Conway Hall, London, 18 April 2015 http://conwayhall.org.uk/event/thewomens-equality-party/ accessed 16 May 2015 states, 'The Women's Equality Party will be a new non-partisan force in British politics bringing together women and men of all ages and backgrounds, united in the campaign for women to enjoy the same rights and opportunities as men so that both sexes can flourish.'
} 
the aims of the women's section manifesto of the much 'older' single sex Women's Party, although no reference is made to the earlier experiment. ${ }^{74}$ The Women's Party, founded by Emmeline and Christabel Pankhurst in 1917, a political failure, is now a forgotten episode of British women's political history. Will the same fate befall the Women's Equality Party formed nearly one hundred years later? It is a question that can only be answered by social commentators in the future.

\footnotetext{
${ }^{74}$ Women's Equality Party, Policy Document (Women's Equality Party, 20 $0^{\text {th }}$ October 2015), p. 4 lists six core objectives - equal representation in politics, business, industry and throughout working life; equal pay and an equal opportunity to thrive; equal parenting and caregiving and shared responsibilities at home to give everyone equal opportunities both in family life and in the work place: an education system that creates opportunities for all children and an understanding of why this matters; equal treatment of women by and in the media, and an end to violence against women.
} 